\title{
Synthesis of nanocrystalline NiAl over a wide composition range by mechanical alloying
}

\author{
B S MURTY, K H S SINGH and S K PABI \\ Department of Metallurgical and Materials Engineering, Indian Institute of Technology, \\ Kharagpur 721 302, India
}

MS received 23 January 1996

\begin{abstract}
The paper reports the synthesis of nanocrystalline NiAl by mechanical alloying of pure metal mixture and a mixture of prealloyed powder with $\mathrm{Ni} / \mathrm{Al}$. A large number of compositions have been studied to establish the phase field of $\mathrm{NiAl}$ in the milled state. The phase field of $\mathrm{NiAl}$ in the ball milled condition was found to be much wider $(10-68 \mathrm{at} \% \mathrm{Ni})$ than its equilibrium phase field (45-59 at. $\% \mathrm{Ni}$ ). The metastable equilibrium achieved by mechanical alloying was identical for a given composition irrespective of the starting ingredients. The crystallite size of $\mathrm{NiAl}$ reached a minimum $(5 \mathrm{~nm})$ at the phase boundary of $\mathrm{NiAl} / \mathrm{Ni}_{3} \mathrm{Al}$.
\end{abstract}

Keywords. Nanocrystals; nickel aluminides; mechanical alloying.

\section{Introduction}

The high specific strength, high melting point and good oxidation resistance of NiAl have made it an advanced high temperature material (Miracle 1993; Noebe et al 1993). However, this aluminide lacks room temperature ductility and sufficient creep resistance. Mechanical alloying (MA) by high energy ball milling, has the potential to enhance the room temperature ductility of $\mathrm{NiAl}$ by bringing it to a nanocrystalline state and also improve upon its creep property by homogeneous dispersion of ceramic particles in its matrix (Benjamin 1976; Koch 1991; Gleiter 1990, 1992; Shingu 1992; Murty 1993; Das and Pabi 1996). Several reports on the synthesis of aluminides in general (Atzmon 1988; Ivanov et al 1990; Hwang et al 1992; Itsukaichi et al 1992, 1993; Nash et al 1992; Scwarz et al 1992; Cardellini et al 1994) and on NiAl in particular (Atzmon 1988; Itsukaichi et al 1992, 1993; Cardellini et al 1994) by MA evidence the dependence of the structure on the particular milling technique. The equilibrium phase field of $\mathrm{NiAl}$ extends over 45-59 at.\% Ni. Itsukaichi et al (1993) studied different compositions in Al-Ni-Ti system after milling in a conventional ball mill and have reported the binary $\mathrm{NiAl}$ phase field to extend from 20 to $65 \mathrm{at} \% \mathrm{Ni}$, after $500 \mathrm{~h}$ of milling. However, it is apparent from their report that they studied only two binary compositions, namely, $\mathrm{Al}_{75} \mathrm{Ni}_{25}$ and $\mathrm{Al}_{50} \mathrm{Ni}_{50}$ in the above composition range. Cardelline et al (1994), working with a Spex Mill, observed the formation of $\mathrm{NiAl}$ at compositions of $\mathrm{Al}_{67} \mathrm{Ni}_{33}$ and $\mathrm{Al}_{50} \mathrm{Ni}_{50}$. The present paper reports the synthesis of NiAl over a wide composition range of $10-68$ at. $\% \mathrm{Ni}$ by $\mathrm{MA}$ of both pure metal mixture and a mixture of an alloy powder $\left(\mathrm{Al}-50 \mathrm{wt} . \% \mathrm{Ni}\right.$, i.e. $\left.\mathrm{Al}_{70} \mathrm{Ni}_{30}\right)$ and pure metals in a planetary mill.

\section{Experimental}

High purity $\mathrm{Ni}$ and $\mathrm{Al}(99.9 \%)$ are mixed in proportions of $\mathrm{Al}_{100-x} \mathrm{Ni}_{x}$ $(x=10,25,40,50,65$ and 68$)$ and mechanically alloyed in a planetary mill (Fritsch Purverisette-5) at $300 \mathrm{rpm}$ using WC container with $10 \mathrm{~mm}$ diameter WC balls and 
a ball to powder weight ratio of $10: 1$. A Ni-Al alloy powder of composition Al$50 \mathrm{wt} . \% \mathrm{Ni}\left(\mathrm{Al}_{70} \mathrm{Ni}_{30}\right)$ was also ball milled under identical conditions with and without the addition of $\mathrm{Al}$ or $\mathrm{Ni}$ to achieve compositions of $\mathrm{Al}_{100-x} \mathrm{Ni}_{x}(x=10,25,30,40,50,65$ and 68). The mechanically alloyed powders were characterized by a Philips PW 1840 $\mathrm{X}$-ray diffractometer with $\mathrm{CuK} \alpha$ radiation at regular intervals of milling. The effective particle size was calculated from the X-ray peak broadening after separating the contribution of strain according to the standard procedure (Murty et al 1993).

\section{Results}

\subsection{Pure metal mixture of $A l_{100-x} N i_{x}(x=10-68)$}

Mechanical alloying of $\mathrm{Ni}$ and $\mathrm{Al}$ powder mixture having nominal composition $\mathrm{Al}_{90} \mathrm{Ni}_{10}$ has not shown the formation of any new phase, in the X-ray diffraction(XRD) pattern even up to $30 \mathrm{~h}$ of milling (table 1 ). The ball milling did not cause any noticeable shift in the Al peaks, while the solubility of Al in Ni (Pearson 1974) calculated from the observed peak shift of $\mathrm{Ni}$ (figure 1), asymptotically reached 8.5 at.\% after $30 \mathrm{~h}$ of milling. The particle size of $\mathrm{Ni}$ and $\mathrm{Al}$ after $30 \mathrm{~h}$ of milling reached about 12 and $20 \mathrm{~mm}$ respectively (table 1 ).

In the case of $\mathrm{Al}_{75} \mathrm{Ni}_{25}$ composition, the $\mathrm{XRD}$ peaks for $\mathrm{Ni}$ and $\mathrm{Al}$ were observed up to $12 \mathrm{~h}$ of milling, as shown in figure 2 . The Ni peak shift at this stage showed that $\mathrm{Ni}$ has taken about 17 at.\% $\mathrm{Al}$ in solution. After $14 \mathrm{~h}$ of milling, $\mathrm{NiAl}$ and small $\mathrm{Al}_{3} \mathrm{Ni}$ peaks appeared in addition to $\mathrm{Ni}$ and $\mathrm{Al}$ peaks. Further milling up to $18 \mathrm{~h}$ resulted in the disappearance of $\mathrm{Ni}$ and $\mathrm{Al}$ peaks, while the $\mathrm{Al}_{3} \mathrm{Ni}$ peaks also disappeared after $20 \mathrm{~h}$ of milling leaving behind single phase $\mathrm{NiAl}$ with some $\mathrm{WC}$ contamination (figure 2). It may be noted that the NiAl, formed during MA in this alloy as well as in all other compositions studied, was ordered as indicated by the (100) superlattice reflection shown by arrowhead in figure 2.

In $\mathrm{Al}_{60} \mathrm{Ni}_{40}$ the formation of single phase $\mathrm{NiAl}$ was complete after $16 \mathrm{~h}$ of milling. In contrast, in $\mathrm{Al}_{50} \mathrm{Ni}_{50}$ residual $\mathrm{Ni}$ peaks persisted at this stage which disappeared only after $24 \mathrm{~h}$ of milling. In both the compositions the particle size of NiAl was $10-12 \mathrm{~nm}$ after $30 \mathrm{~h}$ of milling. Figure 3 is an electron micrograph of NiAl crystallites of $\mathrm{Al}_{50} \mathrm{Ni}_{50}$ composition which confirms their nanocrystalline nature. $\mathrm{Al}_{35} \mathrm{Ni}_{65}$ also manifested similar mode of alloying as $\mathrm{Al}_{50} \mathrm{Ni}_{50}$ excepting that here $\mathrm{Ni}$ peaks disappeared after

Table 1. Phases present and their crystallite sizes after $30 \mathrm{~h}$ of MA.

\begin{tabular}{|c|c|c|c|c|}
\hline \multirow[b]{2}{*}{$\begin{array}{l}\text { Composition } \\
\text { (at. } \% \mathrm{Ni} \text { ) }\end{array}$} & \multicolumn{2}{|c|}{ Pure $\mathrm{Ni}$ and $\mathrm{Al}$ mixture } & \multicolumn{2}{|c|}{ Alloy powder $+\mathrm{Al}$ or $\mathrm{Ni}$} \\
\hline & Phases & $\begin{array}{c}\text { Crystallite size } \\
(\mathrm{nm})\end{array}$ & Phases & $\begin{array}{c}\text { Crystallite size } \\
\text { (nm) }\end{array}$ \\
\hline 10 & $\mathrm{Ni}, \mathrm{Al}$ & 12,20 & $\mathrm{NiAl}, \mathrm{Al}$ & 11,15 \\
\hline 25 & $\mathrm{NiAl}$ & 15 & $\mathrm{NiAl}$ & 19 \\
\hline 30 & - & - & $\mathrm{NiAl}$ & 12 \\
\hline 40 & $\mathrm{NiAl}$ & 12 & $\mathrm{NiAl}$ & 11 \\
\hline 50 & $\mathrm{NiAl}$ & 9 & $\mathrm{NiAl}$ & 9 \\
\hline 65 & $\mathrm{NiAl}$ & 5 & $\mathrm{NiAl}$ & 5 \\
\hline 68 & $\mathrm{NiAl}, \mathrm{Ni}_{3} \mathrm{Al}$ & 5,5 & $\mathrm{NiAl}, \mathrm{Ni}_{3} \mathrm{Al}$ & 5,5 \\
\hline
\end{tabular}




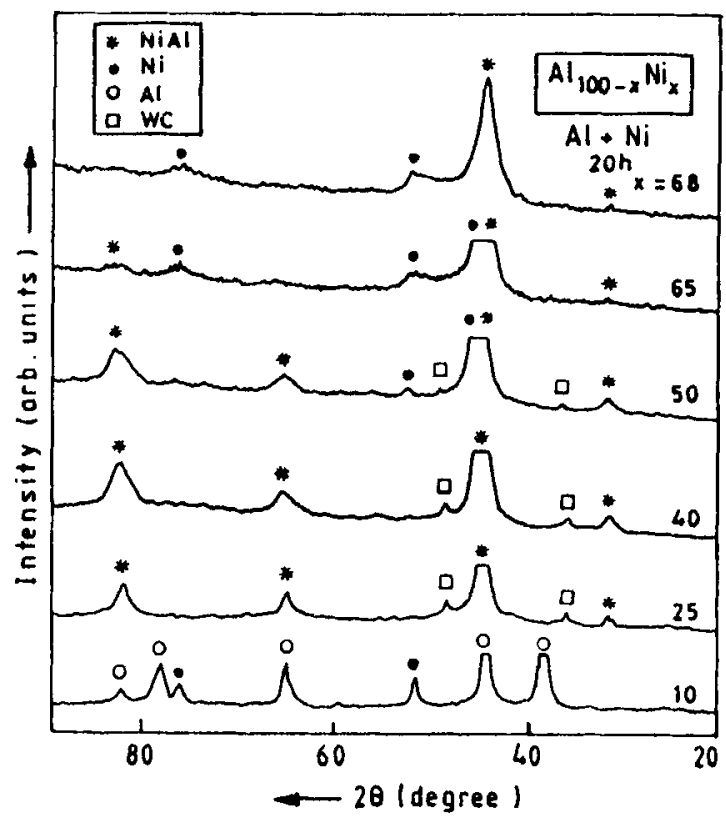

Figure 1. XRD patterns of $\mathrm{Ni}$ and $\mathrm{Al}$ mixtures of $\mathrm{Al}_{100} \mathrm{Ni}_{x}(x=10-68)$ after $20 \mathrm{~h}$ of $\mathrm{MA}$.

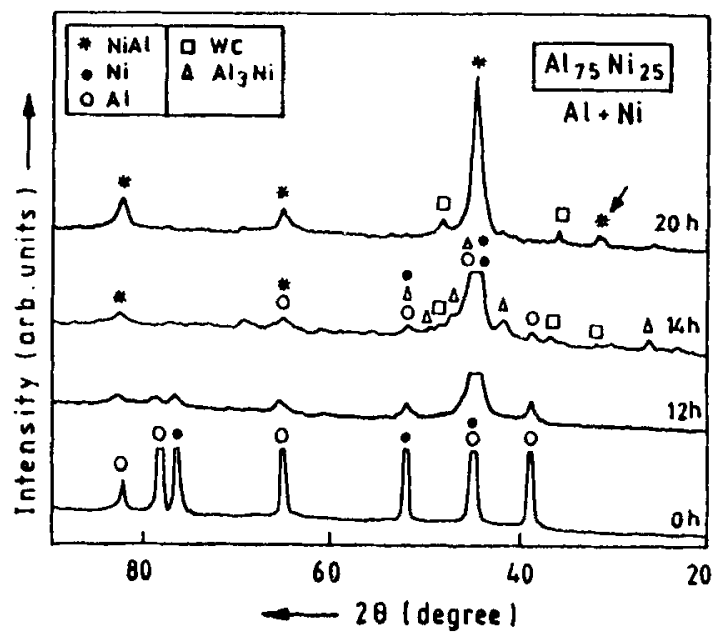

Figure 2. XRD patterns of $\mathrm{Ni}$ and $\mathrm{Al}$ mixture of $\mathrm{Al}_{75} \mathrm{Ni}_{25}$ at different durations of MA. The arrowhead indicates superlattice reflection $(100)$ of $\mathrm{NiAl}$.

$30 \mathrm{~h}$ of milling. The effective particle size $\mathrm{NiAl}$ in this alloy, however, was very small $(5 \mathrm{~nm})$ after $30 \mathrm{~h}$ of milling (table 1$)$.

In $\mathrm{Al}_{32} \mathrm{Ni}_{68}$ composition $\mathrm{NiAl}$ and $\mathrm{Ni}$ peaks were observed in the XRD pattern after $20 \mathrm{~h}$ of milling (figure 1). Further milling up to $30 \mathrm{~h}$ has resulted in the replacement of $\mathrm{Ni}$ with $\mathrm{Ni}_{3} \mathrm{Al}$ (figure 4). In contrast to $\mathrm{NiAl}$, no superlattice reflections of $\mathrm{Ni}_{3} \mathrm{Al}$ could be observed indicating that the $\mathrm{Ni}_{3} \mathrm{Al}$ phase formed was disordered (figure 4). The particle size of $\mathrm{NiAl}$ and $\mathrm{Ni}_{3} \mathrm{Al}$ were about $5 \mathrm{~nm}$ after $30 \mathrm{~h}$ of milling. 


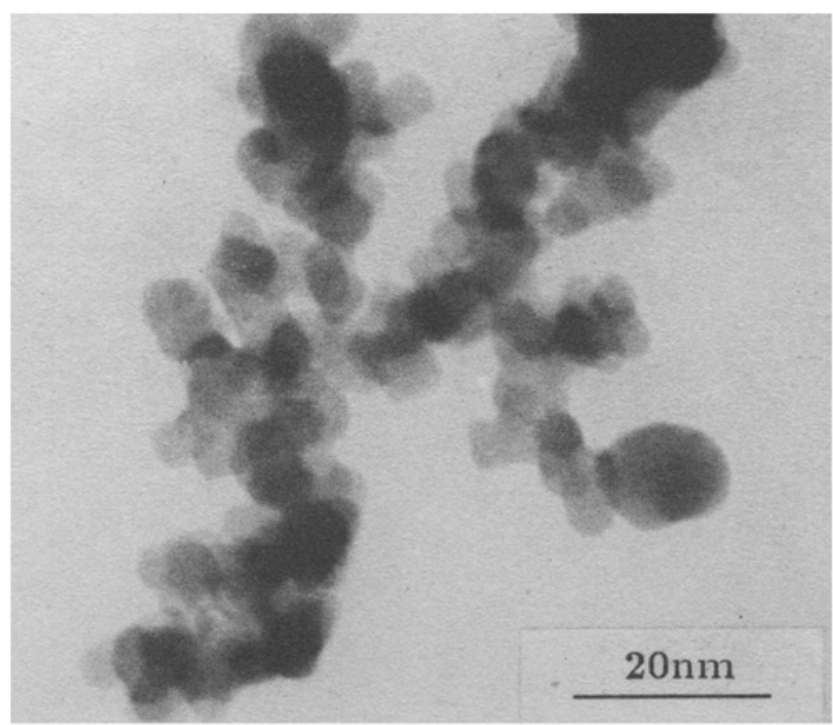

Figure 3. Electron micrograph of $\mathrm{NiAl}$ of $\mathrm{Al}_{50} \mathrm{Ni}_{50}$ composition showing its nanocrystalline nature.

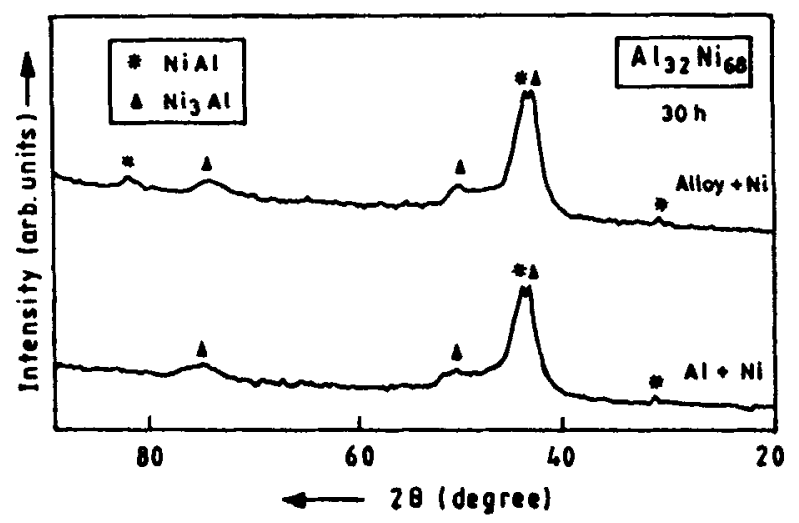

Figure 4. XRD patterns of pure metal mixture and mixture of alloy powder and $\mathrm{Ni}$ of $\mathrm{Al}_{32} \mathrm{Ni}_{68}$ after $30 \mathrm{~h}$ of $\mathrm{MA}$.

\subsection{Ball milling of alloy powder $\left(A l_{70} N i_{30}\right)$}

The modulation of the XRD patterns of alloy powder in course of ball milling is displayed in figure 5. The $\mathrm{Al}_{3} \mathrm{Ni}, \mathrm{Al}_{3} \mathrm{Ni}_{2}$ and $\mathrm{NiAl}$ phases were present in the as received alloy powder. Within $4 \mathrm{~h}$ of milling $\mathrm{Al}_{3} \mathrm{Ni}$ peaks disappeared, $\mathrm{Al}_{3} \mathrm{Ni}_{2}$ followed suit after $8 \mathrm{~h}$ with concommittant large peak shift of the NiAl. Further milling up to $30 \mathrm{~h}$ retained the single phase $\mathrm{NiAl}$ structure with gradual reduction in particle size to $12 \mathrm{~nm}$ (table 1 ). WC contamination became significant after $30 \mathrm{~h}$ of milling (figure 5). 


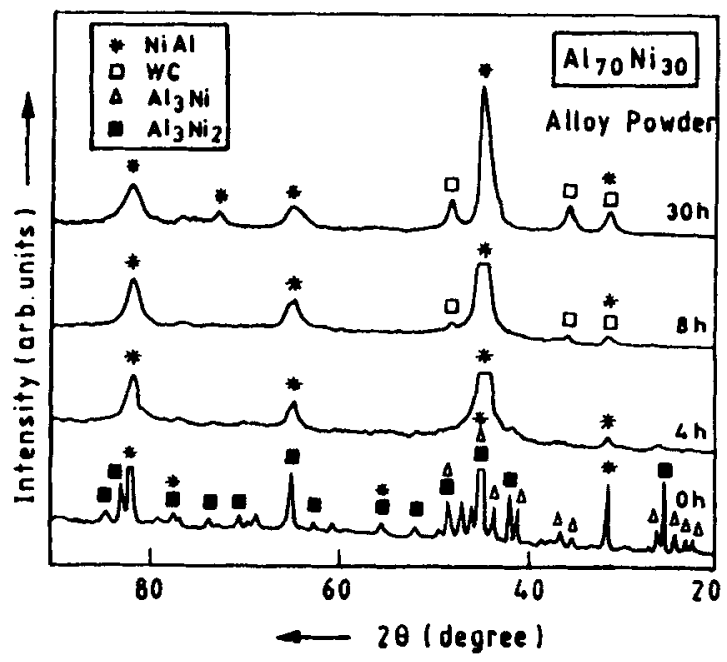

Figure 5. XRD patterns of alloy powder $\left(\mathrm{Al}_{70} \mathrm{Ni}_{30}\right)$ at different durations of milling.

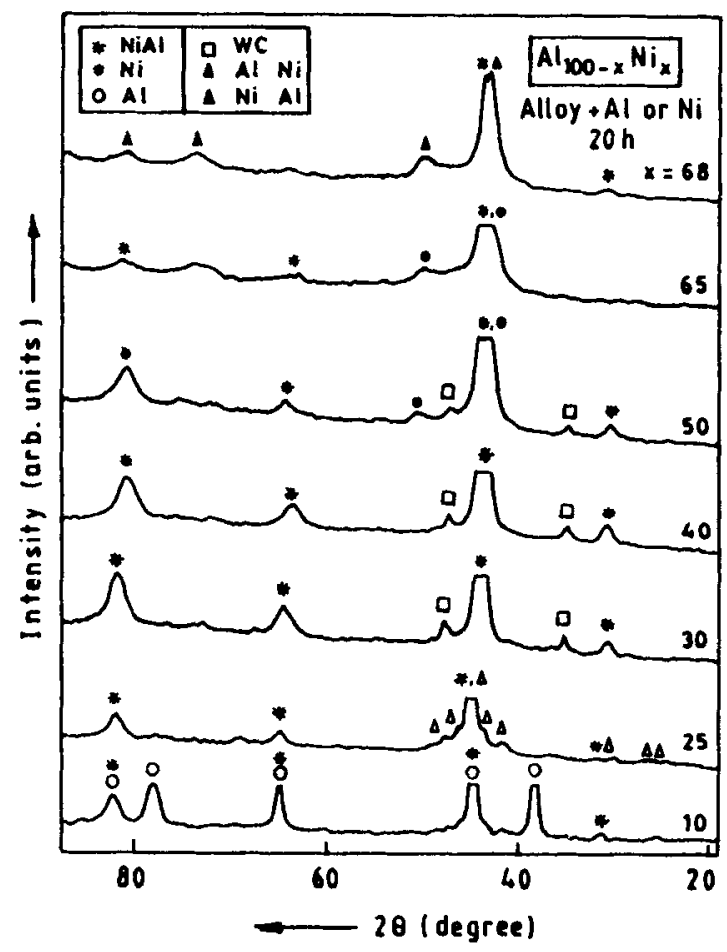

Figure 6. XRD patterns of mixture of alloy powder and $\mathrm{Al}$ or $\mathrm{Ni}$ of $\mathrm{Al}_{100-x} \mathrm{Ni}_{x}(x=10-68)$ after $20 \mathrm{~h}$ of MA.

3.3 Mixture of alloy powder and $A l / N i$ of $A l_{100-x} N i_{x}(x=10-68)$

The XRD patterns of the above mixtures of different compositions corresponding to $\mathrm{Al}_{10-x} \mathrm{Ni}_{x}(x=10,25,30,40,50,65$ and 68$)$ after $20 \mathrm{~h}$ of mechanical alloying are 
displayed in figure 6 . The results after $30 \mathrm{~h}$ of milling are summarized in table 1. Mechanical alloying of mixture of alloy powder and $\mathrm{Al}$ of $\mathrm{Al}_{90} \mathrm{Ni}_{10}$ composition resulted in the disappearance of $\mathrm{Al}_{3} \mathrm{Ni}$ and $\mathrm{Al}_{3} \mathrm{Ni}_{2}$ after $16 \mathrm{~h}$ of milling. However, the $\mathrm{Al}$ and NiAl peaks persisted even after milling up to $30 \mathrm{~h}$. No peak shift in $\mathrm{Al}$ was observed. The $\mathrm{Al}_{75} \mathrm{Ni}_{25}$ obtained from the mixture of alloy powder and $\mathrm{Al}$ showed the presence of $\mathrm{NiAl}, \mathrm{Al}_{3} \mathrm{Ni}$ and $\mathrm{Al}_{3} \mathrm{Ni}_{2}$ up to $16 \mathrm{~h}$ of milling. Milling for $20 \mathrm{~h}$ resulted in the disappearance of $\mathrm{Al}_{3} \mathrm{Ni}_{2}$ (figure 6). Further milling up to $30 \mathrm{~h}$ yielded single phase NiAl.

In the case of composition $\mathrm{Al}_{60} \mathrm{Ni}_{40}, \mathrm{Al}_{50} \mathrm{Ni}_{50}$ and $\mathrm{Al}_{35} \mathrm{Ni}_{65}$, the mode of alloying was quite similar to that of pure metal mixture (cf. figures 1,6 and table 1). However, in $\mathrm{Al}_{32} \mathrm{Ni}_{68}$ composition, $\mathrm{Ni}_{3} \mathrm{Al}$ formation was observed within $20 \mathrm{~h}$ of milling in the case of mixture of alloy powder and $\mathrm{Ni}$, while in the case of pure metal mixture it took $30 \mathrm{~h}$ (cf. figures 1, 4 and 6).

\section{Discussion}

The as received $\mathrm{Al}_{70} \mathrm{Ni}_{30}$ alloy powder showed the presence of $\mathrm{NiAl}$ in addition to the equilibrium $\mathrm{Al}_{3} \mathrm{Ni}$ and $\mathrm{Al}_{3} \mathrm{Ni}_{2}$ phases (figure 5), possibly due to the incomplete peritectic reaction between liquid and $\mathrm{NiAl}$ during the formation of $\mathrm{Al}_{3} \mathrm{Ni}_{2}$. The present results have demonstrated that $\mathrm{Al}_{3} \mathrm{Ni}$ and $\mathrm{Al}_{3} \mathrm{Ni}_{2}$ become unstable during ball milling (figure 5). The narrow composition range of stability of these phases in comparison to NiAl under equilibrium conditions (Massalski 1990) points out that the stability of $\mathrm{Al}_{3} \mathrm{Ni}$ and $\mathrm{Al}_{3} \mathrm{Ni}_{2}$ is more sensitive to structural defects as compared to $\mathrm{NiAl}$. In consequence, the defects induced during milling seem to have made them unstable. However, the relative stabilities of $\mathrm{Al}_{3} \mathrm{Ni}$ and $\mathrm{Al}_{3} \mathrm{Ni}_{2}$ are found to be different at different compositions (figure 6). $\mathrm{Al}_{3} \mathrm{Ni}$ seems to be more stable at its stoichiometric composition, i.e. $\mathrm{Al}_{75} \mathrm{Ni}_{25}$ (figure 6), because only at this composition of pure metal mixture $\mathrm{Al}_{3} \mathrm{Ni}$ forms on milling (figure 2). At any composition away from $\mathrm{Al}_{75} \mathrm{Ni}_{25}$, the stability of $\mathrm{Al}_{3} \mathrm{Ni}$ appears to decrease sharply (figure 6). On the other hand, it may be postulated that the stability of $\mathrm{Al}_{3} \mathrm{Ni}_{2}$ may be more sensitive to the deformation induced defects than composition. This can explain why $\mathrm{Al}_{3} \mathrm{Ni}_{2}$ persists longer than $\mathrm{Al}_{3} \mathrm{Ni}$ in course of ball milling at compositions other than $\mathrm{Al}_{75} \mathrm{Ni}_{25}$.

In the present study $\mathrm{NiAl}$ formation was observed by milling pure metal mixture in the range of 25 at. $\% \mathrm{Ni}$ to 68 at. $\% \mathrm{Ni}$ composition (table 1), while in the case of alloy powder mixed with $\mathrm{Al}$ or $\mathrm{Ni}$, the $\mathrm{NiAl}$ phase was found to exist in the composition range of 10 at. $\% \mathrm{Ni}$ to 68 at. $\% \mathrm{Ni}$. It may also be noted that the phases obtained after prolonged $(30 \mathrm{~h})$ milling of powder blend containing $\geqslant 25 \mathrm{at} . \% \mathrm{Ni}$ were identical, whether the starting materials were pure metal mixture or a mixture of the alloy powder and pure metal, which possibly points out that stability of ball milled NiAl originates from the thermodynamic rather than kinetic reasons.

It is evident from figures 3 and 4 that $\mathrm{NiAl}$ has exceptional ability to maintain its ordered structure while $\mathrm{Ni}_{3} \mathrm{Al}$ is disordered (i.e. reaches higher energy state) under ball milled condition. This fact coupled with the exceptional ability of NiAl to accommodate defects away from equiatomic composition and nearly perfect lattice structure up to its surface (Noebe et al 1993) may enhance the stability of $\mathrm{NiAl}$ in the ball milled condition. The narrow equilibrium phase field of $\mathrm{Ni}_{3} \mathrm{Al}$ in comparison to $\mathrm{NiAl}$ also suggests that the stability of ordered $\mathrm{Ni}_{3} \mathrm{Al}$ is very sensitive to constitutional vacancies 
(Gialancella et al 1992). The data on crystallite size in table 1 indicates that the effective particle size decreases with increase in Ni content in NiAl and reaches about $5 \mathrm{~nm}$ at the phase boundary between $\mathrm{NiAl}$ and $\mathrm{Ni}_{3} \mathrm{Al}$. In contrast, structural refinement is not so remarkable in $\mathrm{Al}_{90} \mathrm{Ni}_{10}$ alloy containing $\mathrm{Al} / \mathrm{NiAl}$ boundaries. Probably, nanocrystalline mixture of the two brittle phases, $\mathrm{NiAl}$ and $\mathrm{Ni}_{3} \mathrm{Al}$, mutually hinder their agglomeration during ball milling.

\section{Conclusion}

In conclusion, $\mathrm{Al}_{3} \mathrm{Ni}, \mathrm{NiAl}$ and $\mathrm{Ni}_{3} \mathrm{Al}$ phases have been synthesized by mechanical alloying in the present study. $\mathrm{Al}_{3} \mathrm{Ni}$ and $\mathrm{Al}_{3} \mathrm{Ni}_{2}$ are found to be unstable while $\mathrm{Al}_{3} \mathrm{Ni}_{5}$ has not formed under the present milling conditions. The $\mathrm{NiAl}$ phase field has been extended by mechanical alloying from 10 to 68 at. $\% \mathrm{Ni}$. Both pure metal mixture and $\mathrm{Al}_{70} \mathrm{Ni}_{30}$ powder blended with pure $\mathrm{Ni}$ or $\mathrm{Al}$ give nearly identical product structure after prolonged ball milling $(30 \mathrm{~h})$. Finally, exceptional refinement of the crystallite size $(5 \mathrm{~nm})$ is achieved at the $\mathrm{NiAl}-\mathrm{Ni}_{3} \mathrm{Al}$ phase boundary.

\section{Acknowledgement}

The authors are grateful to the Department of Science and Technology, Government of India for financial support in carrying out this work vide Grant No. III.4(23)/92-ET. The authors are also thankful to Prof. P Ramachandra Rao for stimulating discussion.

\section{References}

Atzman M 1988 Phys. Rev. Lett. 64487

Benjamin J S 1976 Sci. Am. 23440

Cardellini F, Mazzone G, Montone A and Antisari M V 1994 Acta Metall. Mater. 422445

Das A and Pabi S K 1996 Metals, Materials and Processes (in press)

Gialancella S, Cahn R W, Malagelada J, Surinach S, Baro M D and Yavari A R 1992 Kinetics of ordering transformations in metals, (eds) H Chen and V K Vasudevan (New York: TMS)

Gleiter H 1990 Prog. Mater. Sci. 331

Gleiter H 1992 Nanostructured Mater. 11

Hwang S J, Nash P, Dollar M and Dymek S 1992 Mater. Sci. Forum 88-90 611

Itsukaichi T, Shiga S, Masuyama K. Umemoto M and Okane 11992 Mater. Sci. Forum 88-90 631

Itsukaichi T, Umemoto M and Moreno J G C 1993 Scr. Metall. Mater. 29583

Ivanov E, Grigorieva T, Gdubkova G, Boldyrev V, Fasman A B, Mikhailenko S D and Kalinina O T 1990 Mater. Lett. 751

Koch C C 1991 Processing of metals and alloys, (ed.) R W Cahn (New York: VCH publications) p. 193

Massalski T B 1990 Binary alloy phase diagrams (Ohio: ASM) 1181

Miracle D B 1993 Acta Metall. Mater. 41649

Murty B S 1993 Bull. Mater. Sci. 161

Murty B S, Mohan Rao M and Ranganathan S 1993 Nanostructured Mater. 3459

Nash P, Kim H, Choo H, Ardy H, Hwang S J and Nash A S 1992 Mater. Sci. Forum 88-90 603

Noebe R D, Bowman R R and Nathal M V 1993 Int. Mater. Rev. 38193

Pearson W B 1974 A handbook of lattice spacings and structures of metals and alloys (Oxford: Pergamon Press)

Schwarz R B, Srinivasan S and Desch P B 1992 Mater. Sci. Forum 88-90 595

Shingu P H (ed.) 1992 Mater. Sci. Forum 88-90 